\title{
Allatostatin-type A, kisspeptin and galanin GPCRs and putative ligands as candidate regulatory factors of mantle function
}

\author{
João C.R. Cardoso *, Rute C. Félix, Nadège Bjärnmark, Deborah M. Power* \\ Comparative Endocrinology and Integrative Biology, Centre of Marine Sciences, Universidade do Algarve, Campus de Gambelas, 8005-139 Faro, Portugal
}

\section{A R T I C L E I N F O}

\section{Article history:}

Received 2 September 2015

Received in revised form 2 December 2015

Accepted 12 December 2015

Available online 30 December 2015

\section{Keywords:}

AST-A and KISS GPCRs

Evolution

Genes and transcripts

Molluscs

Peptides

\begin{abstract}
A B S T R A C T
Allatostatin-type A (AST-A), kisspeptin (KISS) and galanin (GAL) G-protein coupled receptor (GPCR) systems share a common ancestral origin in arthropods and the vertebrates where they regulate metabolism and reproduction. The molluscs are the second most diverse phylum in the animal kingdom, they occupy an important phylogenetic position, and their genome is more similar to deuterostomes than the arthropods and nematodes and thus they are good models for studies of gene family evolution and function. This mini-review intends to extend the current knowledge about AST-A, KISS and GAL GPCR system evolution and their putative function in the mollusc mantle. Comparative evolutionary analysis of the target GPCR systems was established by identifying homologues in genomes and tissue transcriptome datasets available for molluscs and comparing them to those of other metazoan systems. Studies in arthropods have revealed the existence of the AST-A system but the loss of homologues of the KISS and GAL systems. Homologues of the insect AST-AR and vertebrate KISSR genes were found in molluscs but putative GALR genes were absent. Receptor gene number suggested that members of this family have suffered lineage specific evolution during the molluscan radiation. In molluscs, orthologues of the insect AST-A peptides were not identified but buccalin peptides that are structurally related were identified and are putative receptor agonists. The identification of AST-AR and KISSR genes in molluscs strengthens the hypotheses that in metazoans members of the AST-AR subfamily share evolutionary proximity with KISSRs. The variable number of receptors and large repertoire of buccalin peptides may be indicative of the functional diversity of the AST-AR/KISSR systems in molluscs. The identification of AST-A and KISS receptors and ligands in the mantle transcriptome indicates that in molluscs they may have acquired a novel function and may play a role in shell development or sensory detection in the mantle.
\end{abstract}

(c) 2015 Elsevier B.V. All rights reserved.

\section{Introduction}

The G-protein coupled receptors (GPCRs) are a large family of receptors that mediate the signalling of many endocrine factors that regulate growth, metabolism, ion homeostasis, stress response and reproduction in metazoans (Dorange, 2015). The GPCR family emerged early during eukaryote evolution and comprises one of the oldest and biggest families of cell membrane receptors (Schioth, 2005; de Mendoza, 2014). Their relatively large size and signature motif of seven highly conserved transmembrane (TM) domains facilitate receptor gene identification and isolation in many phyla. The GPCRs are relevant targets for molecular studies of their evolution and function in metazoan endocrine systems (Cardoso and Larhammar, 2014).

Lophotrocozoans are a speciose protostome group that comprise nearly one-third of all documented marine species (Simakov, 2013; Cock, 2010). Their larvae are distinctive, possessing a horseshoeshaped feeding device with ciliated tentacles named the lophophore, and/or a distinctive larval form known as a trochophore (Nesnidal,

\footnotetext{
* Corresponding authors.

E-mail address: jccardo@ualg.pt (J.C.R. Cardoso).
}

2013). Members of the lophotrocozoans are monophyletic (Nesnidal, 2013) and diverged from ecdysozoans, animals that moult (including arthropods, nematodes and other related phyla) early during the protostome radiation (Erwin, 2011). Their biodiversity, unique morphology, lifecycle and widespread distribution make the lophotrocozoans an interesting group for studying gene evolution and function in metazoans. Nonetheless, although they have a similar gene repertoire and genome organisation to deuterostomes they remain largely unstudied unlike the popular protostome models (e.g. nematodes and insects) that have undergone substantial gene loss and genome rearrangements (Simakov, 2013; Raible, 2005; Miller, 2009; Takahashi, 2009). Therefore lophotrocozoan genomes have the potential to contribute to the understanding of gene and genome evolution since it is likely that features remain that may have been lost or diverged in other protostome models. Studies of the neuropeptide GPCR gene repertoire in lophocotrozoans are scarce and those that exist suggest that a similar receptor gene complement to that of arthropods and vertebrates exists (Clark, 2010; Mirabeau, 2013; Cummins, 2009; Rodet, 2005). In contrast, neuropeptides, putative ligands of GPCRs, have been described in several lophotrocozoans including the marine annelids (Platynereis dumerilii) (Conzelmann, 2013), the polychaete worms (Capitella teleta) 
(Veenstra, 2011), the leech (Helobdella robusta) (Veenstra, 2011), the owl limpet gastropod (Lottia gigantea) (Veenstra, 2010); and in two molluscs, the Akoya pearl oyster (Pinctata fucata) and the Pacific oyster (Crassostrea gigas) (Stewart, 2014).

Recently, we characterised the allatostatin-type A (AST-A) system in arthropods and revealed that it shared a common origin with the kisspeptin (KISS) system present in vertebrates (Felix, 2015) (Fig. 1). Previously, the KISSR gene, that encodes a GPCR, was suggested to have emerged from the same ancestral gene precursor as the galanin receptor (GALR) family (Kim, 2014). In arthropods, the evolution of AST-A receptors and peptide genes has been affected by lineage and species-specific duplication and deletion events. In the malaria mosquito Anopheles coluzzii duplicate receptors persist and it has been hypothesised that they may retain the function of the vertebrate KISS homologue and regulate and integrate the link between metabolism and reproduction (Felix, 2015). Insects are the most diverse animal group and their evolutionary success was powered by the plasticity of their genome that favoured adaption to their external environment (Savard, 2006; C. Tribolium Genome Sequencing et al., 2008; Xia, 2010). This has affected the evolution of the AST-A system and in the malaria mosquitoes AST-A receptors map to highly variable chromosome regions (Felix, 2015). Thus the loss of the KISS and GAL system in insects may be the result of lineage or species-specific gene loss. Characterisation of the homologous systems in invertebrates reveals that they have suffered fewer genome modifications and further studies are essential to better understand gene family evolution in metazoans and to identify alternative animal models in which to study their function.

The molluscs are the most speciose animal phyla after the insects and many possess a unique calcium carbonate shell that is secreted by the mantle. Molluscs are animal models for biomineralization and mantle transcriptomes and shell proteomes have led to the discovery of candidate shell-forming genes and shell matrix proteins (Clark, 2010; Stewart, 2014; Craft, 2010; Joubert, 2010; Milan, 2011; Takeuchi et al., 2012; Zhang et al., 2012; Meng, 2013; Werner, 2013; Freer, 2014; Picone, 2015; Berland, 2011; Marie, 2013), nonetheless this process is still not well understood. Recently, molecular analysis of the Mytilus galloprovincialis mantle transcriptome (Bjärnmark et al. - present issue) identified for the first time in the bivalves orthologues of the vertebrate KISS and GAL receptors and insect AST-AR, and indicates a possible regulatory role for this system in mantle function. In another shelled mollusc L. gigantea, a similar gene repertoire exists but in the annelid $C$. teleta, members of the KISSR, GALR and AST-AR family have evolved differently (Mirabeau, 2013; Felix, 2015), suggesting that lineage specific pressures have affected receptor evolution in lophocotrozoans. This mini-review intends to challenge the recent models proposed for AST-A, KISS and GAL GPCR gene family evolution in metazoans by comparative analysis of their evolution in the molluscs, a phylogenetically important group lying between the arthropods and vertebrates. The potential involvement of AST-A, KISS and GAL GPCR's in mantle function will be explored by analysis of available bivalve mantle transcriptomes.

\section{The allatostatin-type A, kisspeptin and galanin systems}

The AST-A system in arthropods and the KISS and GAL system in vertebrates are well-known peptidergic systems that are involved in the regulation of food-intake, metabolism and reproduction. In insects and other arthropods, AST-As are a large family of small peptides characterised by a conserved C-terminal FGL-amide motif and their production is by proteolytic cleavage of a common prohormone precursor (Bendena, 1999). AST-A peptides were first discovered in cockroaches

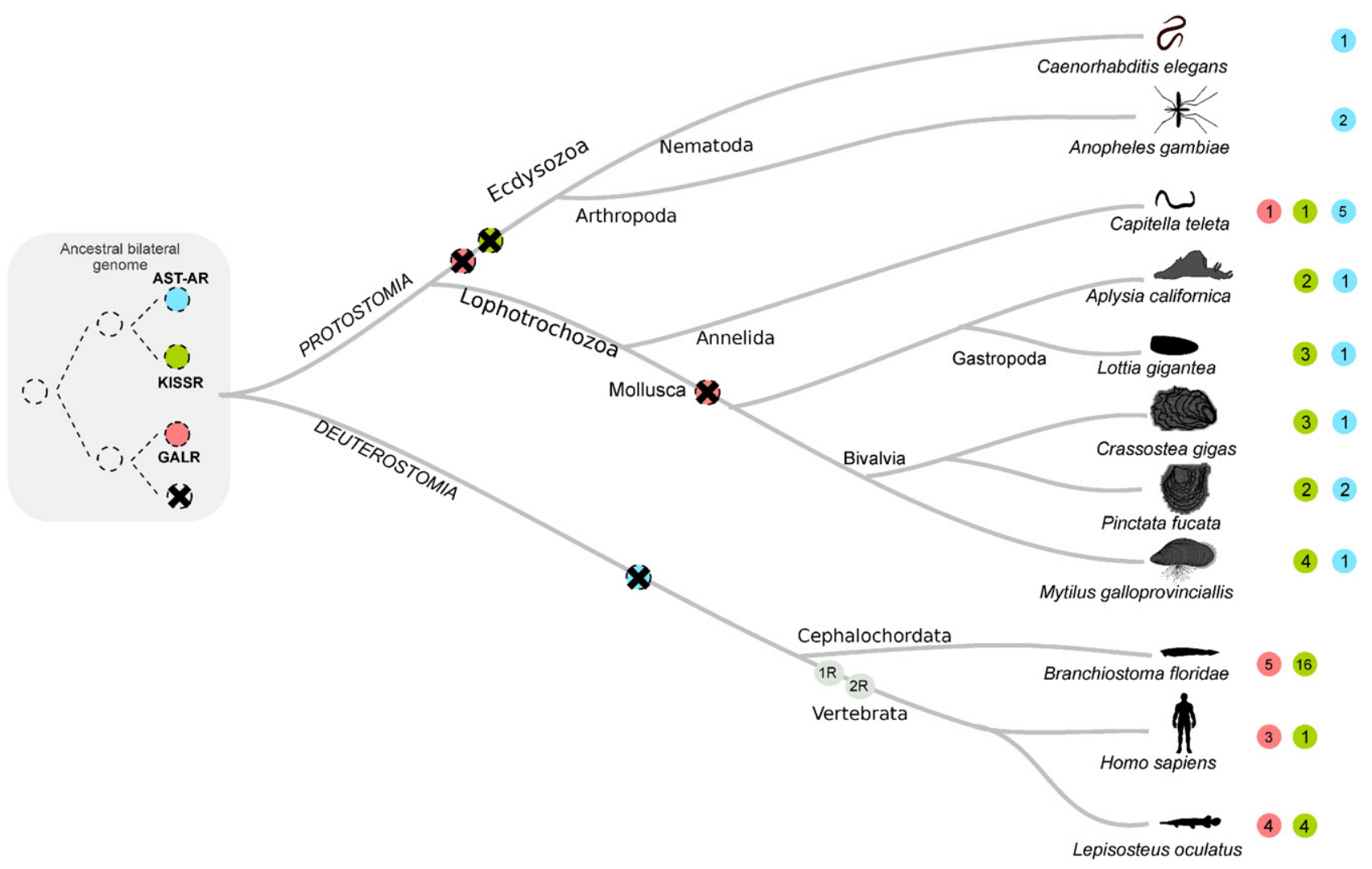

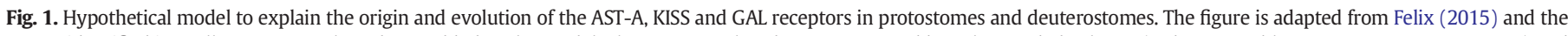

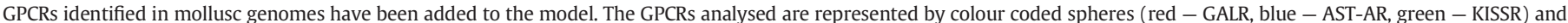

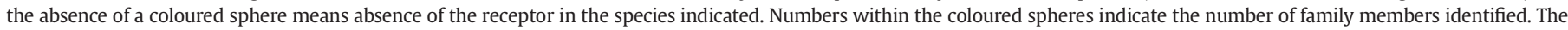

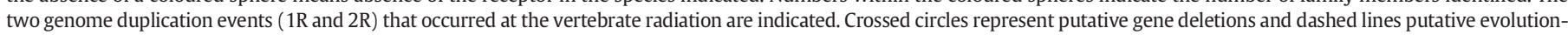
ary events. 
and inhibit the secretion of juvenile hormone $(\mathrm{JH})$ by the corpora allata (CA) (Woodhead, 1989). However, they are now known to regulate food intake in many insects and are potent anti-myotropic factors of gut motility and regulate the activity of several digestive enzymes (Hergarden, 2012; Aguilar, 2003; Spit, 2012). Their cognate receptors remain at present poorly studied and most insects possess a single receptor copy with the exception of the Coleoptera in which the AST-A system is absent and the Diptera where two receptors exist (Felix, 2015; Hauser, 2008; Lenz, 2000; Cardoso, 2012). In Diptera (Drosophila melanogaster and $A$. coluzzii) the paralogous receptors are suggested to be functionally divergent and across species the orthologous receptors seem to have acquired different functions and the duplicate receptors in A. coluzzii respond to blood feeding (Felix, 2015).

The KISS and the GAL systems in deuterostomes shared a common origin with the protostome AST-A system. KISSR and AST-AR were the result of a subsequent gene duplication event in the ancestral bilaterial genome (Fig. 1, (Felix, 2015)). In humans, KISS consists of a group of short amidated peptides that stimulate GnRH release in the hypothalamus. KISS peptides in humans are required for puberty and maintenance of normal reproductive function but also regulate food intake and fat mass production (d'Anglemont de Tassigny, 2010; Wahab, 2013; Brown, 2008). Galanin has similar functions to KISS peptides and is co-expressed with GnRH and changes in energy intake modify its levels in serum and the hypothalamus (Fang, 2015; Lang, 2007). In humans, a single KISSR and three GALR (GALR1, GALR2 and GALR3) genes exist but in the slow evolving genomes of the spotted gar (Lepisosteus oculatus) a ray-finned fish (Amores, 2011), four KISSRs and four GALRs exist and in the cartilaginous elephant shark (Callorhinchus milii) (Venkatesh, 2014) three KISSRs and five GALRs are predicted, suggesting that members of this family expanded early in the vertebrate radiation but subsequently gene deletion occurred in some lineages (Felix, 2015; Kim, 2014; Pasquier, 2012).

\section{Phylogeny and evolution of molluscs}

Mollusca are the second largest phylum of animals. They emerged during the Cambrian period when the vertebrates also emerged (Erwin, 2011). Molluscs have diverse body plans, sizes and shapes. Seven classes of molluscs have been identified that are subdivided into two subphylums based on the possession or not of a calcium carbonate shell: the shell-bearing, Conchifera and the shell-less Aculifera (Fig. 2) (Smith, 2011; Kocot, 2011). The Conchifera subphylum includes; the bivalves with a bivalve shell, the gastropods with a single coiled shell, the cephalopods with a single chambered or inner shell and scaphopods that have a single tusk-shaped shell. The relationships between the different classes remain enigmatic and some gastropods, cephalopods and scaphopods possess no shell (Kocot, 2011; Gonzalez, 2015; Plazzi, 2011; Cunha, 2009). Many shell shapes and structures have been identified and all molluscan shell layered structures are extracellular and result from the secretory activity of the mantle. Based on studies of the engrailed genes (homeodomain transcription factors that participate in establishing the boundaries of the shell-forming fields), it is proposed that the evolution of the shell in Conchifera was a consequence of the concentration of a diffuse shell gland into a single zone of the mantle (or in two mantle zones in bivalves). However, after the shell evolved it was subsequently lost in many lineages (Smith, 2011; Jacobs, 2000). The bivalves and gastropods are highly successful clades and more than 100,000 extant species have been identified. The success of bivalves and gastropods is probably a consequence of their functional plasticity that has allowed them to adapt to different environments and acquire the diversity of forms, lifecycle and feeding strategies that exist today, much as occurred in the insects. Genome and transcriptome datasets are providing insight into how bivalve and gastropod adaptations shaped their genomes and the genes that underpin their unique structure and function (Clark, 2010; Zhang et al., 2012; Meng, 2013; Uliano-Silva, 2014).
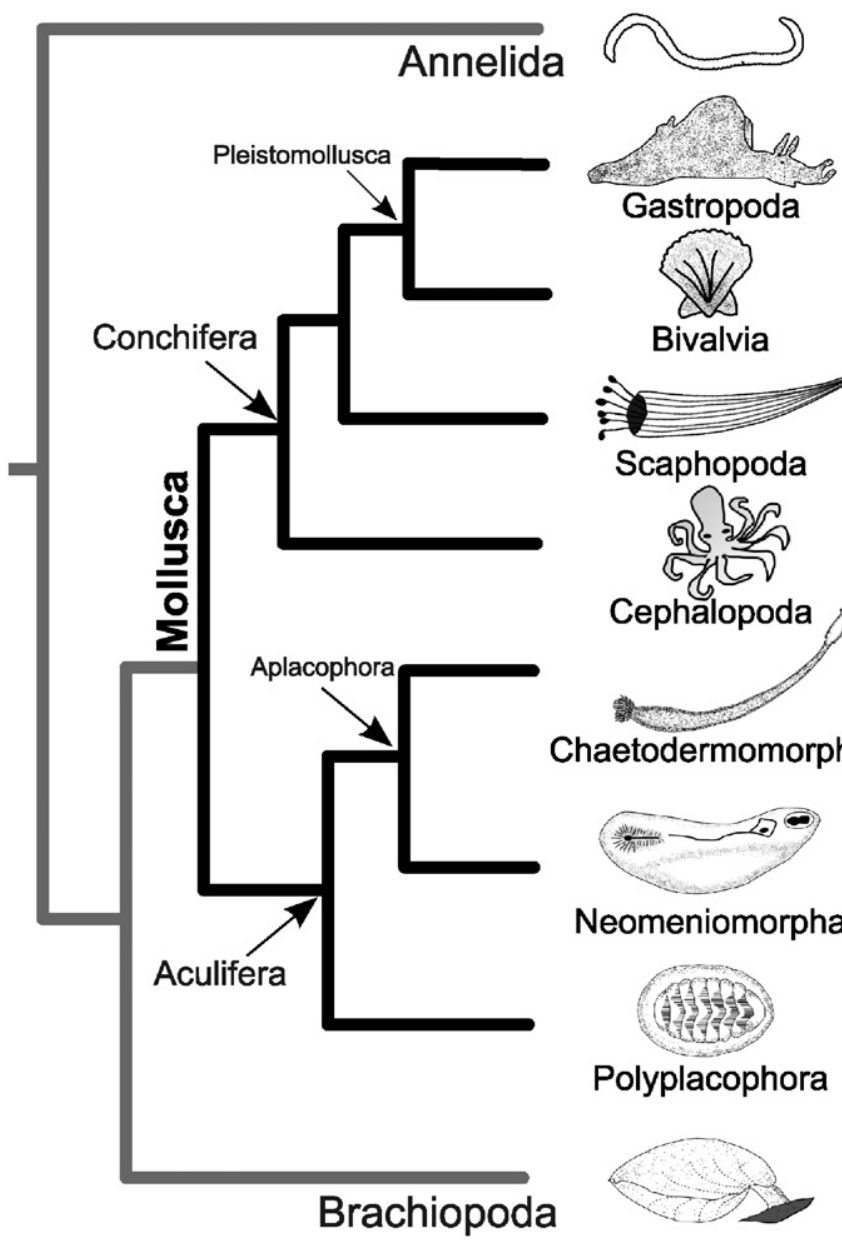

Bivalvia

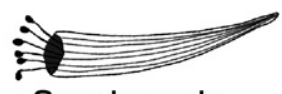

Scaphopoda
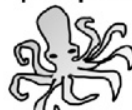

Cephalopoda
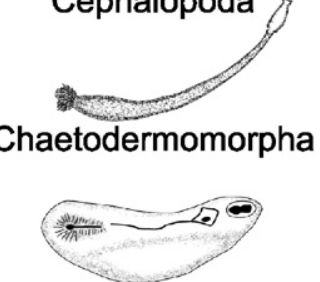

Neomeniomorpha

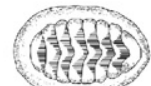

Polyplacophora

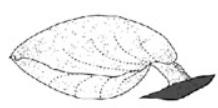

Fig. 2. Dendogram showing the evolutionary position of the mollusc phylum relative to other phyla. Molluscs are sister group of Brachiopoda and they are divided into two main groups (subphylum): the Conchifera that have a shell and the Aculifera that have no shell. Many representatives of the Conchifera subphylum subsequently lost their shells. The figure is adapted from Kocot (2011). The time of divergence between classes is not represented and the images represent an example of one species of each class and are not drawn to scale.

\section{Molecular data for molluscs}

Draft genome assemblies exist for three gastropods, L. gigantea (Simakov, 2013), the freshwater snail (Biomphalaria glabrata) (Raghavan, 2006) and the California sea hare (Aplysia californica) and for two bivalves, $C$. gigas and the Japanese pearl oyster ( $P$. fucata) (Takeuchi et al., 2012) (Table 1). However, transcriptome data mainly from high-throughput sequencing platforms is also available for a large number of molluscs and provides an opportunity to identify genes and to infer their potential function in organism physiology. Transcriptomes exist for several gastropods and include the muscle, ganglion, hepato-pancreas, gonad and gill of the South African Ablone (Haliotis midae) (Picone, 2015) and the mantle of the common limpet (Patella vulgate) (Werner, 2013). For bivalves of the Mytilus species (Craft, 2010; Freer, 2014; Uliano-Silva, 2014), the Antarctic clam (Laternula eliptica) (Clark, 2010), the great scallop (Pecten maximus) (Artigaud, 2014) the black-lip oyster (Pinctada margaritifera) (Joubert, 2010) and the Japanese scallop (Patinopecten yessoensis) (Ding, 2015) mantle transcriptomes exist and for the Manila clam (Ruditapes philippinaru) and the deep-sea hydrothermal vent mussel (Bathymodiolus azoricus) transcriptomes for the gills and digestive gland (Milan, 2011) and gills (Bettencourt, 2010) exist, respectively. Most of the transcriptome data for molluscs is available at the NCBI database as Expressed Sequence Tags EST; 1.137,560 sequences, July 
Table 1

List of the mollusc genomes searched in the analysis. Searches were performed against the deduced peptides.

\begin{tabular}{|c|c|c|c|}
\hline Species & Common name & Assembly & Database \\
\hline Lottia gigantea & Owl limpet & GCA_000327385.1 & ENSEMBL \\
\hline Aplysia californica & California sea hare & AplCal 2.0 & Broad Institute \\
\hline Biomphalaria glabrata & Freshwater snail & BglaB1 & NCBI/VectorBase \\
\hline Crassostrea gigas & Pacific oyster & GCA_000297895.1 & ENSEMBL \\
\hline Pinctada fucata & Japanese pearl oyster & ver 1.0 & http://marinegenomics.oist.jp \\
\hline
\end{tabular}

2015) or as short sequence reads (SRA; 1833 experiments, July 2015). Recently, with the aim of further investigating the physiological mechanisms and biomolecules that regulate shell growth and development, we generated an RNAseq assembled library from the mantle of the Mediterranean mussel (M. galloprovincialis) (for library construction and assembly details, see Bjärnmark et al.- present issue). The available mantle datasets in NCBI were used to establish if the AST-A, KISS and GAL receptor genes were present and to assess if functional specialisation of members of this gene family occurred in association with the evolution of the mantle during bivalve evolution.

\section{Receptor members in molluscs}

In molluscs as well as in other lophocotrozoan, studies of GPCR evolution are scarce but orthologues of the insect AST-AR and of the vertebrate KISSR genes were recently described in a gastropod, L. gigantea (Mirabeau, 2013; Felix, 2015). No orthologues for the vertebrate GALR genes were found. In other lophocotrozoans, such as the annelid C. teleta, genes encoding receptors of the three subfamilies were identified as well as multiple AST-AR genes ( 5 genes) indicating that members of this receptor family were under different evolutionary

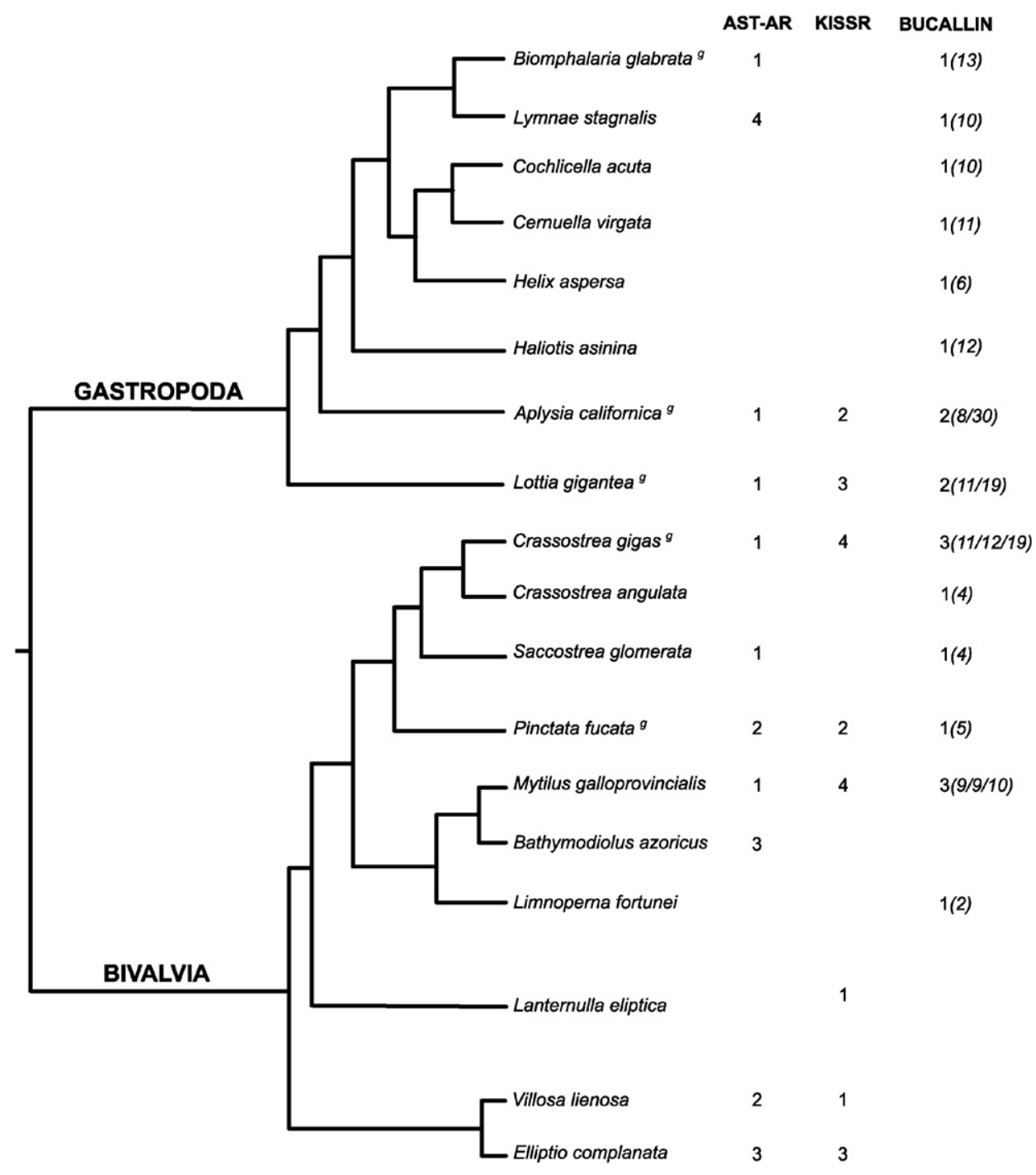

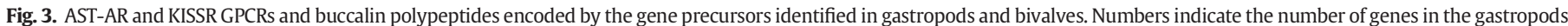

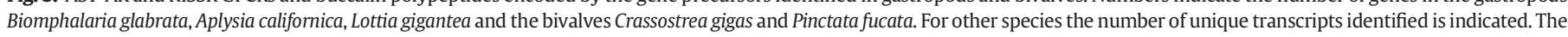

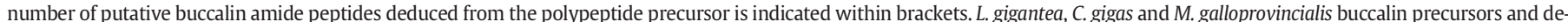

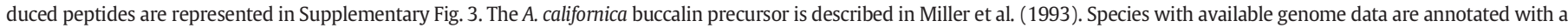

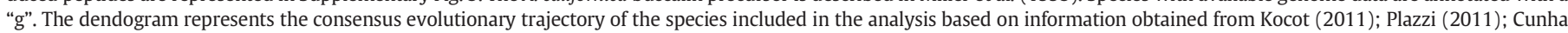
(2009); Razkin (2015). 
Table 2

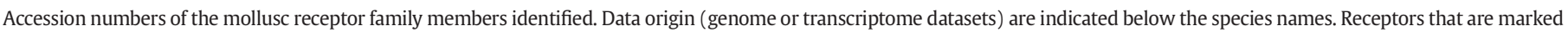
with an asterisk "*" were not used for the phylogenetic analysis due to the incomplete nature of the sequence.

\begin{tabular}{|c|c|c|c|}
\hline & Species & AST-AR & KISSR \\
\hline \multirow[t]{10}{*}{ Gastropods } & Aplysia californica & XP_005097945.1 & XP_005100004.1 \\
\hline & (genome) & & XP_005105721.1 \\
\hline & Lottia gigantea & LotgiG108200 & LotgiG51656 \\
\hline & (genome) & & LotgiG102897 \\
\hline & & & LotgiG92705 \\
\hline & $\begin{array}{l}\text { Biomphalaria glabrata } \\
\text { (genome) }\end{array}$ & BGLB009144RA & \\
\hline & Lymnaea stagnalis & CAB77263.1 & \\
\hline & (heart and CNS transcriptome) & CAB77264.1 & \\
\hline & & CAB77265.1 & \\
\hline & & CAB77262.1 & \\
\hline \multirow[t]{20}{*}{ Bivalves } & Crassostrea gigas & CGI_10013414 & CGI_10023500 \\
\hline & (genome) & & CGI_10017836 \\
\hline & & & CGI_10023499* \\
\hline & & & CGI_10013413* \\
\hline & $\begin{array}{l}\text { Saccostrea glomerata } \\
\text { (gills, digestive gland transcriptome) }\end{array}$ & GBJD01010463.1 & \\
\hline & Pinctata fucata & aug1.0_4555.1_08937.t1 & aug1.0_585.1_36598.t1 \\
\hline & (genome) & aug1.0_32239.1_12096.t1 & aug1.0_33075.1_26626.t1 \\
\hline & Mytilus galloprovincialis & MgaR1 & MgaR2 \\
\hline & (mantle transcriptome) & & MgaR3 \\
\hline & & & MgaR4 \\
\hline & & & MgaR5 \\
\hline & Bathymodiolus azoricus & SRR067874.129271.2* & \\
\hline & (gill transcriptome) & SRR067874.397942.2* & \\
\hline & & SRR067874.146318.2* & \\
\hline & $\begin{array}{l}\text { Laternula eliptica } \\
\text { (mantle transcriptome) }\end{array}$ & & $18,961,079$ \\
\hline & Villosa lienosa & JR495027.1 & JR509684.1 \\
\hline & (muscle, mantle, gill transcriptome) & JR511751.1 & \\
\hline & Elliptio complanata & GAHW01014852.1 & GAHW01047360.1 \\
\hline & (whole animal transcriptome) & GAHW01038350.1 & GAHW01035593.1* \\
\hline & & GAHW01078092.1* & GAHW01061991.1 \\
\hline
\end{tabular}

pressure during the lophotrocozoan radiation (Mirabeau, 2013; Felix, 2015).

The receptor sequences from the insects (D. melanogaster, DAR1, FBgn0028961 and DAR2 FBgn0039595 and A. coluzzii, GPRALS1 and GPRALS2) (Felix, 2015)) and L. gigantea (Mirabeau, 2013; Felix, 2015) were used to search genomic (Table 1 ) and other available mollusc databases (protein, transcriptome shotgun assembly (TSA) ESTs, taxid:6447, http://www.ncbi.nlm.nih.gov) for putative AST-AR and KISSR/GALR gene family members. Putative mollusc receptor sequences with a cut off e-value $<-10$ were retrieved, analysed and translated into the most probable coding sequence using the translator tool available from Expasy (http://web.expasy.org/translate/). Articles reporting assembled SRA datasets were also used to recover sequences as were raw reads (454 sequencing) from the gills of the deep-sea hydrothermal vent mussel (B. azoricus). Query of unassembled SRA datasets from other Mollusca produced a large number of short sequence hits that were difficult to interpret and were not taken in consideration in this study. Assembled mantle transcriptomes of $M$. galloprovincialis (Bjärnmark et al. - present issue), L. eliptica and P. maximus (downloaded from the Polar Data Centre NERC-BAS Datasets available from the British Antarctic Survey) were also searched for AST-AR and KISSR/GALR family members. To confirm the identity of the mollusc protein sequences, all the retrieved DNA sequences for putative AST-AR and KISSR/GALR were used to interrogate the NCBI vertebrate (taxid:7742) and insect (taxid:6960) datasets using Blastp.

In general, AST-AR and KISSR/GALR receptor number varied between molluscs and multiple receptors of the same subfamily were found in some species and were retrieved from mantle and other tissue transcriptomes indicating that the receptors have a widespread tissue distribution (Fig. 3, Table 2). Sequence homologues of AST-AR and KISSR were identified but no GALR gene or transcripts were retrieved from molluscs with available genome and transcriptome data
(Table 2). In the gastropods, a putative AST-AR and two putative KISSR genes were identified in the genome of A. californica and a single AST-AR and three KISSR genes (LotgiG102897 and LotgiG92705) were retrieved from the genome of $L$. gigantea (Table 2 ). In the assembled genome of $B$. glabrata a single AST-AR-gene was found and in the great pond snail, $L$. stagnalis four AST-ARs genes were previously described (Saunders, 2000) but no orthologues of the KISSR gene were identified (Fig. 3).

In bivalves, multiple AST-AR and KISSR sequences were identified and the number of genes/transcripts identified was species specific (Table 2, Fig. 3 ). In oyster $C$. gigas genome a single AST-AR gene (CGI_10013414 in scaffold960) and two complete KISSR genes (CGI_10017836 in scaffold72 and CGI_10023500 in scaffold1258) were found. In the genome of this species two other KISSR genes were also predicted (CGI_10013413 in scaffold960 and CGI_10023499 in scaffold1258) but their identity remains to be confirmed, as the sequences were very incomplete (Table 2). In the available genome of the oyster P. fucata two AST-AR and two KISSR genes were retrieved. In the transcriptome (gills and digestive gland) of the Sydney rock oyster (Saccostrea glomerata) a single AST-AR transcript was found and the $M$. galloprovincialis mantle transcriptome yielded a single transcript for AST-AR and four transcripts for KISSR although it was not possible to establish if the latter transcripts were the result of alternative gene splicing or corresponded to the product of different genes, as no assembled genome for this species or for other mussels are available. In contrast, in the deep-sea hydrothermal vent mussel (B. azoricus), another species of the Mytilidae family, three transcripts for AST-AR were retrieved from the gill transcriptome but no representatives of the KISSR family were identified. In the freshwater mussels, $V$. lienosa (muscle, mantle and gill cDNA library) and E. complanata (whole animal cDNA library) two and three AST-ARs and one and three KISSR transcripts were obtained, respectively. In the L. eliptica mantle transcriptome only one putative KISSR was retrieved (Table 2). 


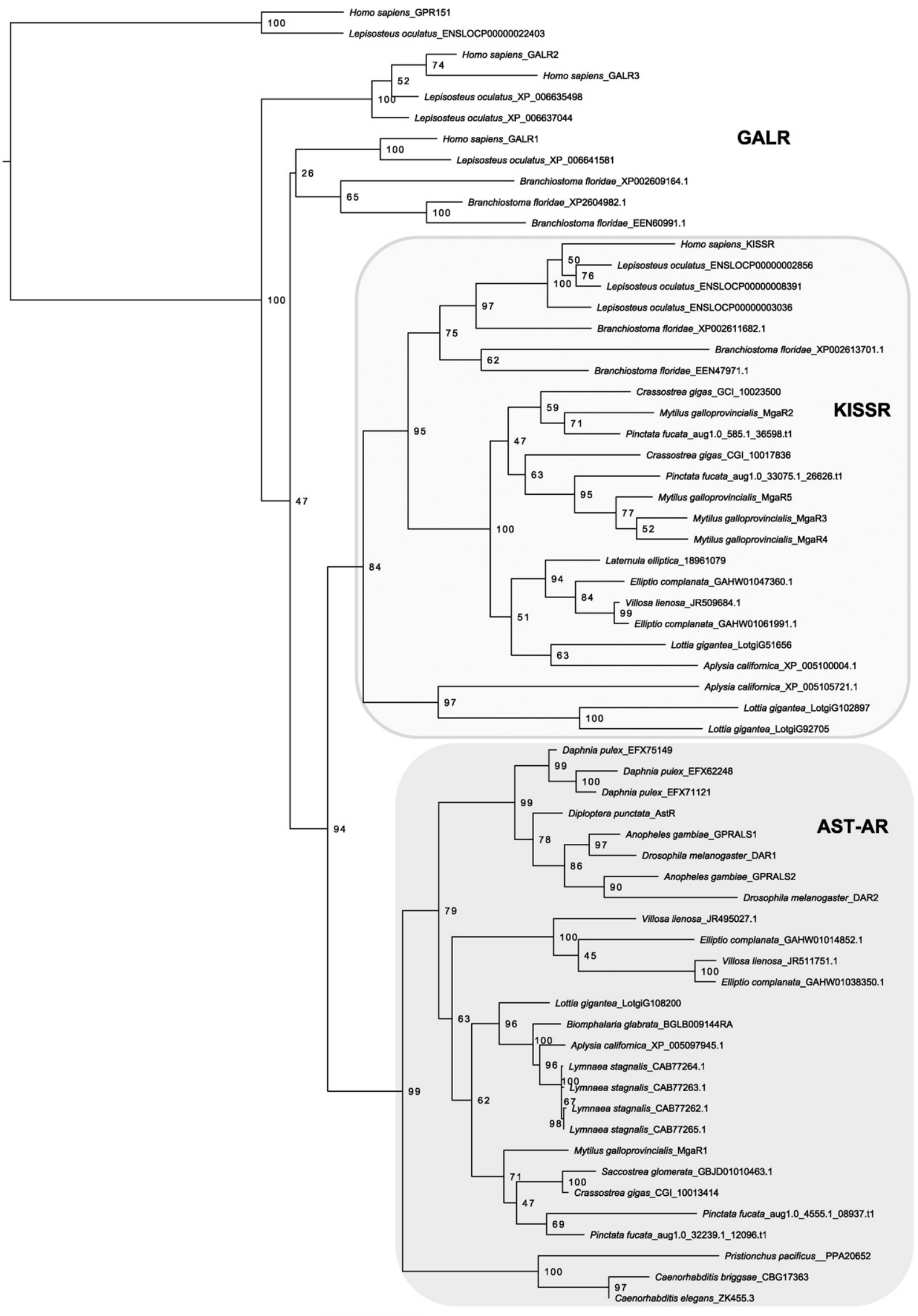


Phylogenetic analysis of bivalve AST-ARs and KISSRs with homologues from the insects (D. melanogaster, A. coluzzii and water flea, Daphnia pulex), the nematodes (Caenorhabdiis briggsae and Pristonchus pacificus), an early deuterostome representative, the amphioxus (Branchiostoma floridae), and two vertebrates, a fish (L. oculatus) and human, confirmed their identity. Trees were built using a sequence alignment of TM1 to TM7 domains using the: a) Maximum likelihood (ML) method in PhyML, (http://www.atgc-montpellier.fr), b) the Neighbour Joining (NJ) method in Mega 5 (Kumar, 2008) and c) Bayesian interference (BI) in MrBayes 3.2 (Ronquist, 2012). ML and NJ phylogenetic trees were constructed using the best model that characterises protein family evolution (obtained from the Protest 2.4 server, (Abascal, 2005)). To infer statistical support for phylogenetic tree branching 100 and 1000 bootstrap iterations were used for ML and NJ, respectively and probability values were extracted for BI. The ML, NJ and BI methods generated phylogenetic trees with identical topologies (Fig. 4 and Supplementary Figs. 1 and 2).

The consensus ML tree (Fig. 4) revealed that most of the duplicate receptor genes seem to have arisen through lineage specific or species-specific events. Within the AST-AR cluster the two P. fucata genes and the four $L$. stagnalis genes were the result of species-specific duplications but the two members identified in the freshwater mussels ( $V$. lienosa and E. complanata) were potentially the consequence of a gene duplication that affected the Unionidae family. In the KISSR clade a similar scenario seems to have occurred but the clustering of one of the A. californica KISSR and two L. gigantea KISSR genes outside the deuterostome-protostome main receptor cluster suggests that the ancestral KISSR gene may have duplicated prior to the protostomedeuterostome divergence and that the descendants of the two gene copies only persisted in gastropods (Fig. 4). In M. galloprovincialis the four KISSR mantle transcripts grouped in two different branches of the ML phylogenetic tree along with the duplicate orthologues found in the oyster genomes, suggesting that prior to the divergence of the Mytyloidea order, receptor gene duplication may have occurred. Three of the M. galloprovincialis KISSR (MgaR3, 4 and 5) transcripts share high sequence similarity and it remains to be established if they are mantle specific gene isoforms or are also expressed in other tissues. The presence of diverse members of the AST-AR and KISSR gene family in the mantle of several bivalves (M. galloprovincialis, Laternula eliptica, Villosa lienosa) and the characterisation of multiple receptor transcripts in the mantle of $M$. galloprovincialis highlight that they have a role in mantle function, which will be explored in future studies.

\section{Putative ligands}

Mollusc genomes do not contain AST-A peptides and buccalins have been proposed to be homologues of the insect AST-A peptides (Veenstra, 2010). Both buccalins and AST-A are small peptides that possess a C-terminal amidated region, they are encoded by large gene families and multiple peptides arise by proteolysis of a single polypeptide precursors (Fig. 5 and Supplementary Fig. 3). Buccalins inhibit mollusc muscle contraction and regulate feeding behaviour (Veenstra, 2010; Cropper, 1988; Miller et al., 1993). Buccalin was first isolated from the gastropod accessory radula closer muscle (Cropper, 1988; Miller et al., 1993) and in L. gigantea proteolysis of the polypeptide precursor generates 19 peptides, 7 (GLDQYGFTGQLamide) and 3 (GLDQYGFAGQLamide) of which are identical (Veenstra, 2010) (Fig. 5 and Supplementary Fig. 3). Gastropod and bivalve genomes and transcriptomes were interrogated with $L$. gigantea mature buccalin peptides and orthologues of the genes encoding the full polypeptide precursors retrieved to establish, which tissues produce them.

A novel buccalin-like gene (LotgiG87724) was identified in the L. gigantea genome and the predicted buccalin-like peptides ended with a $\mathrm{V}$-amide. The putative peptide precursor probably generates at least 11 mature $\mathrm{V}$-amide peptides, 9 of which were identical (PFDTLASGLVamide, Supplementary Fig. 3 ). In the $C$. gigas genome 3 genes for putative bucallin precursors were predicted (Supplementary Fig. 3). The predicted $C$. gigas buccalin gene mapped to scaffold750 and had the potential to produce a high number of mature peptides. Although relatively few identical peptides would be generated. Of the $19 \mathrm{~L}$-amide peptides predicted to arise by proteolytic processing of the C. gigas buccalin precursor polypeptide, 4 (ALDRYGFFGGLamide peptides) and 2 (ALDQYGFAGSLamide) would be identical and the sequence of the remaining peptides would be unique. The other two C. gigas genes are buccalin-like genes (that map to scaffold1329 and SuperContig C20578) and 100\% identical but SuperContig C20578 was 13 aa shorter than scaffold1329. Both the predicted oyster buccalinlike polypeptide precursors generate $\mathrm{V}$-amide peptides and scaffold1329 encoded a polypeptide precursor containing 12 peptides of which 5 were identical.

In the M. galloprovincialis mantle transcriptome, 3 putative buccalin polypeptide precursors orthologues of the $\mathrm{C}$. gigas genes were retrieved and designated Mga1-3. The deduced mature protein sequence of Mga1 was 32\% and 34\% similar to Mga 2 and 3 and generated 9 different buccalin L-amide peptides (Supplementary Fig. 3 ). The deduced mature polypeptide sequence of Mga 3 was 100\% identical to Mga 2 with the exception that it was 13 aa shorter (Supplementary Fig. 3). Mga 2 and 3 were predicted to produce 10 and 9 buccalin-like peptides, respectively of which 7 were PFDRLASGLVamide peptides. Comparison of the mollusc buccalin L-amide and V-amide peptides revealed that members of each peptide subfamily shared a conserved $\mathrm{D}$ at the $\mathrm{N}$ terminus and a conserved $\mathrm{G}$ at the $\mathrm{C}$-terminus. L-amide peptides were separated by 5 residues (D-( $5 X)-G$ ) and V-amide peptides were separated by 4 residues (D-(4X)-G) (Fig. 5 and data not shown). Putative buccalin transcripts (L-amide and $\mathrm{V}$-amide) were also identified in other molluscs and analysis of transcript expression revealed that they were present in the mantle and several other tissues (heart, gill, muscle and reproductive tissues) (Table 3 ).

In annelids, buccalin peptides or AST-A precursors were not identified in C. teleta and H. robusta (Veenstra, 2011). However, in P. dumerilii 3 ASTA precursors were characterised (Conzelmann, 2013) suggesting that buccallin and its precursors may be a mollusc specific innovation. The peptide coding potential of the expressed product of the buccalin gene and the number of unique family members, many of which seem to be species-specific, is intriguing and raises questions about how they evolved and their physiological importance in molluscs.

\section{Conclusion}

Members of the AST-A, KISS and GAL GPCR systems had a common evolutionary origin but after their divergence family members suffered distinct evolutionary pressures as revealed by the receptor and peptide gene repertoire present in animal genomes (Fig. 1). Homologues of the arthropod AST-AR and vertebrate KISSR and putative peptide ligands were identified in molluscs but no GALR genes or transcripts were found suggesting that they were lost in this lineage (Fig. 1). The buccalins were identified as putative AST-AR ligands and may be a mollusc specific innovation. Multiple copies of buccalin, some identical and others with minor sequence variations, were predicted when the genes

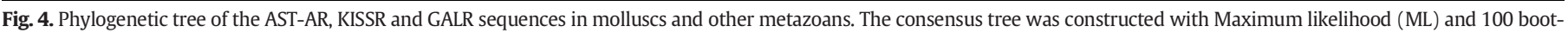

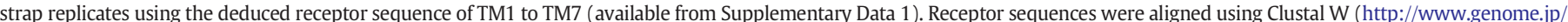

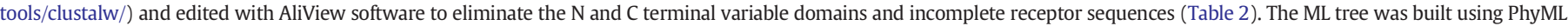

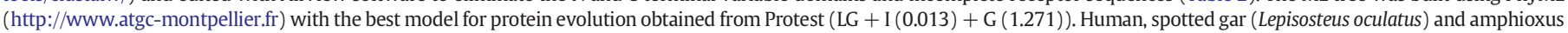

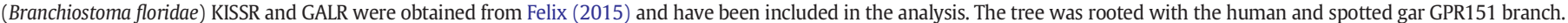




\section{VERTEBRATE}

Human KISS 1

\section{INSECT}

Drosophila_AST-A1

Drosophila AST-A2

Drosophila AST-A3

Drosophila AST-A4

Anopheles_AST-A1

Anopheles AST-A2

Anopheles_AST-A3

Anopheles AST-A4

Anopheles_AST-A5

MOLLUSC

Lottia_P159314.1a

Lottia_P159314.1b

Lottia_P159314.1c

Lottia P159314.1defghik

Lottia_P159314.1jln

Lottia_P159314.1m

Lottia P159314.10

Lottia_P159314.1p

Lottia P159314.1q

Lottia_P159314.1r

Lottia_P159314.1s

Lottia_P87724.1_abchidefg

Lottia-P87724.1j

Lottia_P87724.1k

Oyster scaffold750 a

Oyster_scaffold750_b

Oyster scaffold750 c

Oyster_scaffold750_d

Oyster_scaffold750_ek

Oyster scaffold750 fl

Oyster_scaffold750_gm

Oyster scaffold750 hn

Oyster_scaffold750_i

Oyster scaffold750 $j$

Oyster_scaffold750_1

Oyster scaffold1329

Oyster_scaffold1329_b

oyster_scaffold1329_c

Oyster scaffold1329 d

Oyster_scaffold1329_e

Oyster scaffold1329 $f$

Oyster_scaffold1329_g

Oyster_scaffold1329_h

Mytilus1_a

Mytilus1_b

Mytilus1_c

Mytilus 1 d

Mytilus1_e

Mytilus $1-f$

Mytilus1_g

Mytilus1_h

Mytilus1_i

Mytilus2_a

Mytilus2 b

Mytilus2_c

Mytilus2-d
YNWNS-FGLRF- $\mathrm{NH}_{2}$

VERYA-FGL- $\mathrm{NH}_{2}$

LP-VYN-FGL- $\mathrm{NH}_{2}$

SRPYS-FGL- $\mathrm{NH}_{2}$

TTRPQPFN-FGL- $\mathrm{NH}_{2}$

SP-KYN-FGL- $\mathrm{NH}_{2}$

LP-HYN-FGL- $\mathrm{NH}_{2}$

TASGNGAGSAYRYH-FGL- $\mathrm{NH}_{2}$

RAYD-FGLE- $\mathrm{NH}_{2}$

LPNRYN-FGL- $\mathrm{NH}_{2}$

GMDKFG-FAGGV- $\mathrm{NH}_{2}$

GLDKFG-FTGQL- $\mathrm{NH}_{2}$

DMDSFG-FAGQL- $\mathrm{NH}_{2}$

GLDQYG-FTGQL- $\mathrm{NH}_{2}$

GLDQYG-FAGQL- $\mathrm{NH}_{2}$

GLDHYG-FAGQL- $\mathrm{NH}_{2}$

GFDQFG-FAGQL- $\mathrm{NH}_{2}$

GLDHYG-FAGQL- $\mathrm{NH}_{2}$

GLDQLG-FTGQL- $\mathrm{NH}_{2}$

QMDIFG-YRGQL- $\mathrm{NH}_{2}$

QSIDKYS-FLGAGI- $\mathrm{NH}_{2}$

PFDTLAS-GLV- $\mathrm{NH}_{2}$

QMDSLAS-GLV- $\mathrm{NH}_{2}$

LVDSLAS-GLV- $\mathrm{NH}_{2}$

ALDRYS-FSGSL- $\mathrm{NH}_{2}$

GLDRYS-FYGGL- $\mathrm{NH}_{2}$

ALDRYG-FFGGL- $\mathrm{NH}_{2}$

ALDQYG-FAGSL- $\mathrm{NH}_{2}$

ALDRYS-FMGGL- $\mathrm{NH}_{2}$

KLDQYG-FAGRL- $\mathrm{NH}_{2}$

ALDRYG-FVGTL- $\mathrm{NH}_{2}$

KLDQYS-FMGNL- $\mathrm{NH}_{2}$

RLDSHRYFG-SL- $\mathrm{NH}_{2}$

LYPYWYYRQGGSPIYTQTRGIDRFFL-GL- $\mathrm{NH}_{2}$

ALDSHRYFGSL- $\mathrm{NH}_{2}$

QFDRLAS-GLI- $\mathrm{NH}_{2}$

RLDSVAS-GLV- $\mathrm{NH}_{2}$

RLDTIAS-GLV- $\mathrm{NH}_{2}$

RLDSIAS-GLV- $\mathrm{NH}_{2}$

MIDSLAS-GLV- $\mathrm{NH}_{2}$

MMDSLAS-GLV- $\mathrm{NH}_{2}$

TMDSLAS-GLV- $\mathrm{NH}_{2}$

TLDSLAS-GLV- $\mathrm{NH}_{2}$

KMDMYR-FHGSL- $\mathrm{NH}_{2}$

KIDYAR-FLGSL- $\mathrm{NH}_{2}$

SKYDRYM-FAPSL- $\mathrm{NH}_{2}$

RLDRFSYFGNL- $\mathrm{NH}_{2}$

GMDKLSYFGSL- $\mathrm{NH}_{2}$

GLDRLSFFGGL- $\mathrm{NH}_{2}$

RMDRLSYFGGL- $\mathrm{NH}_{2}$

LPVSIRGIDKYSLFGSL- $\mathrm{NH}_{2}$

SIDQDRLQE-IL-NH

LFERLAS-GLV- $\mathrm{NH}_{2}$

PFDRLAS-GLV- $\mathrm{NH}_{2}$

EFDRLAS-GLV- $\mathrm{NH}_{2}$

MDPLAS-SLV- $\mathrm{NH}_{2}$

Fig. 5. Comparison of the human KISS, insect AST-A peptides and mollusc buccalin and buccalin-like peptides. Amino acid conservation with the FGL motif characteristic of the insect AST-A is highlighted in red. The conserved D and $\mathrm{G}$ motifs characteristic of L-amide and V-amide buccalin peptides are in bold. Only unique peptides deduced from the complete precursor sequences reported in Supplementary Fig. 3 are represented. The letters after the accession number indicate identical peptides predicted in the full peptide precursor, and the peptides are listed according to their order of appearance in the polypeptide precursor (e.g. "a" is the first deduced mature peptide and so on). The Crassostea gigas and Mytilus galloprovincialis V-amide peptides correspond to scaffold1329 and Mga2, respectively (Supplementary Fig. 3).

and transcripts of a given species were analysed and this suggests that this family of peptides may have a diversity of unexplored functions in molluscs. The production of multiple copies of identical buccalin peptides from the same polypeptide precursor is intriguing and we hypothesize that this may favour a rapid and strong response to stimulus; future studies will be required to answer this question. Data from the molluscs support the hypothesis that AST-AR shares greater evolutionary proximity to KISSR than to GALR and that the members of 
Table 3

Accession numbers and origin (EST and TSA) of the mollusc bucallin and bucallin-like peptide transcripts.

\begin{tabular}{|c|c|c|c|}
\hline Species & Type & EST & TSA \\
\hline \multirow[t]{2}{*}{ Aplysia californica } & V-amide & & $\begin{array}{l}\text { GBDA01109291 } \\
\text { (gills) } \\
\text { GBBG01041237 } \\
\text { (ovotestis) } \\
\text { GBBE01067718 } \\
\text { (hermaphroditic glands, reproductive tissue) } \\
\text { GBCZ01124427 } \\
\text { (rhinophores, tentacles) } \\
\text { GBAQ01052379 } \\
\text { (hepatopancreas) } \\
\text { GBBV01059111 } \\
\text { (digestive tissue) } \\
\text { GBAV01130732 } \\
\text { (muscle) } \\
\text { GBBW01013096 } \\
\text { (heart) }\end{array}$ \\
\hline & L-amide & $\begin{array}{l}\text { FF081227 } \\
\text { (multi tissues) }\end{array}$ & $\begin{array}{l}\text { GBCZ01016503 } \\
\text { (rhinophores, tentacles) } \\
\text { EZ114739 } \\
\text { (whole animal) } \\
\text { GBCZ01016502 } \\
\text { (rhinophores, tentacles) } \\
\text { GBAV01060166 } \\
\text { (muscle) } \\
\text { GBCZ01016503 } \\
\text { (rhinophores, tentacles) } \\
\text { GBDA01058080 } \\
\text { (gills) } \\
\text { GBBG01042508 } \\
\text { (ovotestis) }\end{array}$ \\
\hline Crassostrea angulata & V-amide & & $\begin{array}{l}\text { JT997155.1 } \\
\text { (whole animal) }\end{array}$ \\
\hline Crassostrea gigas & L-amide & $\begin{array}{l}\text { CU988287 } \\
\text { (whole animal) } \\
\text { HS248228 } \\
\text { (gill, muscle, mantle) } \\
\text { HS240090 } \\
\text { (gill, muscle, mantle) }\end{array}$ & \\
\hline Limnoperna fortunei & L-amide & & $\begin{array}{l}\text { GBGC01006916 } \\
\text { (mantle, gills, digestive gland, abductor muscle) }\end{array}$ \\
\hline \multirow[t]{2}{*}{ Mytilus galloprovincialis } & L-amide & & $\begin{array}{l}\text { Mga_1 } \\
\text { (mantle) }\end{array}$ \\
\hline & V-amide & & $\begin{array}{l}\text { Mga_2 } \\
\text { (mantle) } \\
\text { Mga_3 } \\
\text { (mantle) }\end{array}$ \\
\hline Saccostrea glomerata & L-amide & & $\begin{array}{l}\text { GBJD01013364 } \\
\text { (whole animal) }\end{array}$ \\
\hline
\end{tabular}

both receptor families suffered lineage and species-specific evolution during the mollusc radiation. The absence of GALR genes in mollusc and insect genomes, and their presence in annelids suggest that they were transmitted from the ancestral bilateria genome to protostomes but that during their radiation the receptor genes were lost or retained due to different evolutionary pressures. In the Lophocotrozoa genomes GALR genes were deleted prior to the mollusc expansion and in the Ecdysozoa they were deleted, probably at the same time as the KISSR genes and prior to the radiation of the nematode and arthropod lineages. The existence in molluscs of an AST-AR system similar to that in insects and a KISSR system similar to that in vertebrates highlights the biological importance of these regulatory networks. Co-expression of AST-AR and KISSR and a variety of bucallin peptides by the mantle suggests that they probably have a regulatory role in this tissue. We propose that during evolution of the molluscs the AST-A/KISS peptidergic system recruited a new ligand, buccalin, and also acquired, as yet unidentified, mantle specific functions.

Supplementary data to this article can be found online at http://dx. doi.org/10.1016/j.margen.2015.12.003.

\section{Acknowledgements}

This study was supported by the European Union Seventh Framework Programme under grant agreement no 605051 (CACHE-ITN). JCRC is funded by an auxiliary research contract under the project UID/Multi/04326/2013, NA is funded by CACHE-ITN and RCF is in receipt of FCT SFRH/BPD/89811/2012 grant.

\section{References}

Dorange, I., 2015. New paradigms in GPCR drug discovery. Curr. Top. Med. Chem. Fredriksson, R., Schioth, H.B., 2005. The repertoire of G-protein-coupled receptors in fully sequenced genomes. Mol. Pharmacol. 67, 1414-1425.

de Mendoza, A., Sebe-Pedros, A., Ruiz-Trillo, I., 2014. The evolution of the GPCR signaling system in eukaryotes: modularity, conservation, and the transition to metazoan multicellularity. Genome Biol. Evol. 6, 606-619.

Cardoso, J.C.R., Larhammar, D., 2014. Comparative evolution of peptide hormone-binding GPCRs: a route to understanding functional complexity. Gen. Comp. Endocrinol. 209, $1-2$.

Simakov, O., Marletaz, F., Cho, S.J., Edsinger-Gonzales, E., Havlak, P., Hellsten, U., Kuo, D.H., Larsson, T., Lv, J., Arendt, D., Savage, R., Osoegawa, K., de Jong, P., Grimwood, J., Chapman, J.A., Shapiro, H., Aerts, A., Otillar, R.P., Terry, A.Y., Boore, J.L., Grigoriev, 
I.V., Lindberg, D.R., Seaver, E.C., Weisblat, D.A., Putnam, N.H., Rokhsar, D.S., 2013. Insights into bilaterian evolution from three spiralian genomes. Nature 493, 526-531.

Cock, J., Tessmar-Raible, K., Boyer, C., Viard, F., 2010. Introduction to Marine Genomics. first ed. Springer, Netherlands.

Nesnidal, M.P., Helmkampf, M., Meyer, A., Witek, A., Bruchhaus, I., Ebersberger, I., Hankeln, T., Lieb, B., Struck, T.H., Hausdorf, B., 2013. New phylogenomic data support the monophyly of Lophophorata and an Ectoproct-Phoronid clade and indicate that Polyzoa and Kryptrochozoa are caused by systematic bias. BMC Evol. Biol. 13, 253.

Erwin, D.H., Laflamme, M., Tweedt, S.M., Sperling, E.A., Pisani, D., Peterson, K.J., 2011. The Cambrian conundrum: early divergence and later ecological success in the early history of animals. Science 334, 1091-1097.

Raible, F., Tessmar-Raible, K., Osoegawa, K., Wincker, P., Jubin, C., Balavoine, G., Ferrier, D. Benes, V., de Jong, P., Weissenbach, J., Bork, P., Arendt, D., 2005. Vertebrate-type intron-rich genes in the marine annelid Platynereis dumerilii. Science 310, 1325-1326.

Miller, D.J., Ball, E.E., 2009. The gene complement of the ancestral bilaterian - was Urbilateria a monster? J. Biol. 8, 89 .

Takahashi, T., McDougall, C., Troscianko, J., Chen, W.C., Jayaraman-Nagarajan, A., Shimeld, S.M., Ferrier, D.E., 2009. An EST screen from the annelid Pomatoceros lamarckii reveals patterns of gene loss and gain in animals. BMC Evol. Biol. 9, 240

Clark, M.S., Thorne, M.A., Vieira, F.A., Cardoso, J.C., Power, D.M., Peck, L.S., 2010. Insights into shell deposition in the Antarctic bivalve Laternula elliptica: gene discovery in the mantle transcriptome using 454 pyrosequencing. BMC Genomics 11, 362.

Mirabeau, O., Joly, J.S., 2013. Molecular evolution of peptidergic signaling systems in bilaterians. Proc. Natl. Acad. Sci. U. S. A. 110, E2028-E2037.

Cummins, S.F., Erpenbeck, D., Zou, Z., Claudianos, C., Moroz, L.L, Nagle, G.T., Degnan, B.M., 2009. Candidate chemoreceptor subfamilies differentially expressed in the chemosensory organs of the mollusc Aplysia. BMC Biol. 7, 28.

Rodet, F., Lelong, C., Dubos, M.P., Costil, K., Favrel, P., 2005. Molecular cloning of a molluscan gonadotropin-releasing hormone receptor orthologue specifically expressed in the gonad. Biochim. Biophys. Acta 1730, 187-195.

Conzelmann, M., Williams, E.A., Krug, K., Franz-Wachtel, M., Macek, B., Jekely, G., 2013. The neuropeptide complement of the marine annelid Platynereis dumerilii. BMC Genomics 14, 906.

Veenstra, J.A., 2011. Neuropeptide evolution: neurohormones and neuropeptides predicted from the genomes of Capitella teleta and Helobdella robusta. Gen. Comp. Endocrinol. 171, 160-175.

Veenstra, J.A., 2010. Neurohormones and neuropeptides encoded by the genome of Lottia gigantea, with reference to other mollusks and insects. Gen. Comp. Endocrinol. 167, $86-103$.

Stewart, M.J., Favrel, P., Rotgans, B.A., Wang, T., Zhao, M., Sohail, M., O'Connor, W.A., Elizur, A., Henry, J., Cummins, S.F., 2014. Neuropeptides encoded by the genomes of the Akoya pearl oyster Pinctata fucata and Pacific oyster Crassostrea gigas: a bioinformatic and peptidomic survey. BMC Genomics 15, 840

Felix, R.C., Trindade, M., Pires, I.R., Fonseca, V.G., Martins, R.S., Silveira, H., Power, D.M., Cardoso, J.C., 2015. Unravelling the evolution of the allatostatin-type A, KISS and galanin peptide-receptor gene families in bilaterians: insights from Anopheles mosquitoes. PLoS One 10, e0130347.

d'Anglemont de Tassigny, X., Colledge, W.H., 2010. The role of kisspeptin signaling in reproduction. Physiology 25, 207-217.

Wahab, F., Atika, B., Shahab, M., 2013. Kisspeptin as a link between metabolism and reproduction: evidences from rodent and primate studies. Metab. Clin. Exp. 62, 898-910.

Kim, D.K., Yun, S., Son, G.H., Hwang, J.I., Park, C.R., Kim, J.I., Kim, K., Vaudry, H., Seong, J.Y., 2014. Coevolution of the spexin/galanin/kisspeptin family: spexin activates galanin receptor type II and III. Endocrinology 155, 1864-1873.

Savard, J., Tautz, D., Lercher, M.J., 2006. Genome-wide acceleration of protein evolution in flies (Diptera). BMC Evol. Biol. 6, 7.

C. Tribolium Genome Sequencing, Richards, S., Gibbs, R.A., Weinstock, G.M., Brown, S.J., Denell, R., Beeman, R.W., Gibbs, R., Beeman, R.W., Brown, S.J., Bucher, G., Friedrich, M., Grimmelikhuijzen, C.J., Klingler, M., Lorenzen, M., Richards, S., Roth, S., Schroder, R., Tautz, D., Zdobnov, E.M., Muzny, D., Gibbs, R.A., Weinstock, G.M., Attaway, T., Bell, S., Buhay, C.J., Chandrabose, M.N., Chavez, D., Clerk-Blankenburg, K.P., Cree, A., Dao, M., Davis, C., Chacko, J., Dinh, H., Dugan-Rocha, S., Fowler, G., Garner, T.T., Garnes, J., Gnirke, A., Hawes, A., Hernandez, J., Hines, S., Holder, M., Hume, J., Jhangiani, S.N., Joshi, V., Khan, Z.M., Jackson, L., Kovar, C., Kowis, A., Lee, S., Lewis, L.R., Margolis, J., Morgan, M., Nazareth, L.V., Nguyen, N., Okwuonu, G., Parker, D., Richards, S., Ruiz, S.J., Santibanez, J., Savard, J., Scherer, S.E., Schneider, B., Sodergren, E., Tautz, D., Vattahil, S., Villasana, D., White, C.S., Wright, R., Park, Y., Beeman, R.W. Lord, J., Oppert, B., Lorenzen, M., Brown, S., Wang, L., Savard, J., Tautz, D., Richards, S., Weinstock, G., Gibbs, R.A., Liu, Y., Worley, K., Weinstock, G., Elsik, C.G., Reese, J.T., Elhaik, E., Landan, G., Graur, D., Arensburger, P., Atkinson, P., Beeman, R.W., Beidler, J., Brown, S.J., Demuth, J.P., Drury, D.W., Du, Y.Z., Fujiwara, H., Lorenzen, M., Maselli, V., Osanai, M., Park, Y., Robertson, H.M., Tu, Z., Wang, J.J., Wang, S., Richards, S., Song, H., Zhang, L., Sodergren, E., Werner, D., Stanke, M., Morgenstern, B., Solovyev, V., Kosarev, P., Brown, G., Chen, H.C., Ermolaeva, O., Hlavina, W. Kapustin, Y., Kiryutin, B., Kitts, P., Maglott, D., Pruitt, K., Sapojnikov, V., Souvorov, A., Mackey, A.J., Waterhouse, R.M., Wyder, S., Zdobnov, E.M., Zdobnov, E.M., Wyder, S., Kriventseva, E.V., Kadowaki, T., Bork, P., Aranda, M., Bao, R., Beermann, A., Berns, N., Bolognesi, R., Bonneton, F., Bopp, D., Brown, S.J., Bucher, G., Butts, T., Chaumot, A., Denell, R.E. Ferrier, D.E., Friedrich, M., Gordon, C.M., Jindra, M., Klingler, M., Lan, Q., Lattorff, H.M., Laudet, V., von Levetsow, C., Liu, Z., Lutz, R., Lynch, J.A., da Fonseca, R.N., Posnien, N., Reuter, R., Roth, S., Savard, J., Schinko, J.B., Schmitt, C., Schoppmeier, M., Schroder, R., Shippy, T.D., Simonnet, F., Marques-Souza, H., Tautz, D., Tomoyasu, Y., Trauner, J., Van der Zee, M., Vervoort, M., Wittkopp, N., Wimmer, E.A., Yang, X., Jones, A.K., Sattelle, D.B., Ebert, P.R., Nelson, D., Scott, J.G., Beeman, R.W., Muthukrishnan, S., Kramer, K.J., Arakane, Y., Beeman, R.W., Zhu, Q., Hogenkamp, D., Dixit, R., Oppert, B.,
Jiang, H., Zou, Z., Marshall, J., Elpidina, E., Vinokurov, K., Oppert, C., Zou, Z., Evans, J., Lu, Z., Zhao, P., Sumathipala, N., Altincicek, B., Vilcinskas, A., Williams, M., Hultmark D., Hetru, C., Jiang, H., Grimmelikhuijzen, C.J., Hauser, F., Cazzamali, G., Williamson, M., Park, Y., Li, B., Tanaka, Y., Predel, R., Neupert, S., Schachtner, J., Verleyen, P., Raible, F., Bork, P., Friedrich, M., Walden, K.K., Robertson, H.M., Angeli, S., Foret, S., Bucher, G., Schuetz, S., Maleszka, R., Wimmer, E.A., Beeman, R.W., Lorenzen, M., Tomoyasu, Y., Miller, S.C., Grossmann, D., Bucher, G., 2008. The genome of the model beetle and pest Tribolium castaneum. Nature 452, 949-955.

Xia, A., Sharakhova, M.V., Leman, S.C., Tu, Z., Bailey, J.A., Smith, C.D., Sharakhov, I.V., 2010 Genome landscape and evolutionary plasticity of chromosomes in malaria mosquitoes. PLoS One 5, e10592.

Craft, J.A., Gilbert, J.A., Temperton, B., Dempsey, K.E., Ashelford, K., Tiwari, B., Hutchinson, T.H., Chipman, J.K., 2010. Pyrosequencing of Mytilus galloprovincialis cDNAs: tissuespecific expression patterns. PLoS One 5, e8875.

Joubert, C., Piquemal, D., Marie, B., Manchon, L., Pierrat, F., Zanella-Cleon, I., CochennecLaureau, N., Gueguen, Y., Montagnani, C., 2010. Transcriptome and proteome analysis of Pinctada margaritifera calcifying mantle and shell: focus on biomineralization. BMC Genomics 11, 613.

Milan, M., Coppe, A., Reinhardt, R., Cancela, L.M., Leite, R.B., Saavedra, C., Ciofi, C., Chelazzi, G., Patarnello, T., Bortoluzzi, S., Bargelloni, L., 2011. Transcriptome sequencing and microarray development for the Manila clam, Ruditapes philippinarum: genomic tools for environmental monitoring. BMC Genomics 12, 234.

Takeuchi, T., Kawashima, T., Koyanagi, R., Gyoja, F., Tanaka, M., Ikuta, T., Shoguchi, E., Fujiwara, M., Shinzato, C., Hisata, K., Fujie, M., Usami, T., Nagai, K., Maeyama, K., Okamoto, K., Aoki, H., Ishikawa, T., Masaoka, T., Fujiwara, A., Endo, K., Endo, H., Nagasawa, H. Kinoshita, S., Asakawa, S. Watabe, S, Satoh, N., 2012. Draft genome of the pearl oyster Pinctada fucata: a platform for understanding bivalve biology. DNA Res. 19, 117-130.

Zhang, G., Fang. X., Guo, X., Li, L., Luo, R., Xu, F., Yang, P., Zhang, L., Wang, X.. Oi. H., Xiong, Z., Que, H., Xie, Y., Holland, P.W., Paps, J., Zhu, Y., Wu, F., Chen, Y., Wang, J., Peng, C., Meng, J., Yang, L., Liu, J., Wen, B., Zhang, N., Huang, Z., Zhu, Q., Feng, Y., Mount, A. Hedgecock, D., Xu, Z., Liu, Y., Domazet-Loso, T., Du, Y., Sun, X., Zhang, S., Liu, B., Cheng, P., Jiang, X., Li, J., Fan, D., Wang, W., Fu, W., Wang, T., Wang, B., Zhang, J., Peng, Z., Li, Y., Li, N., Wang, J., Chen, M., He, Y., Tan, F., Song, X., Zheng, Q., Huang, R. Yang, H., Du, X., Chen, L., Yang, M., Gaffney, P.M., Wang, S., Luo, L., She, Z., Ming, Y., Huang, W., Zhang, S., Huang, B., Zhang, Y., Qu, T., Ni, P., Miao, G., Wang, J., Wang, Q., Steinberg, C.E., Wang, H., Li, N., Qian, L., Zhang, G., Li, Y., Yang, H., Liu, X., Wang, J. Yin, Y., Wang, J., 2012. The oyster genome reveals stress adaptation and complexity of shell formation. Nature 490, 49-54.

Meng, J., Zhu, Q.H., Zhang, L.L., Li, C.Y., Li, L., She, Z.C., Huang, B.Y., Zhang, G.F., 2013. Genome and transcriptome analyses provide insight into the euryhaline adaptation mechanism of Crassostrea gigas. PLoS One 8.

Werner, G.D., Gemmell, P., Grosser, S., Hamer, R., Shimeld, S.M., 2013. Analysis of a deep transcriptome from the mantle tissue of Patella vulgata Linnaeus (Mollusca: Gastropoda: Patellidae) reveals candidate biomineralising genes. Mar. Biotechnol. 15, 230-243.

Freer, A., Bridgett, S., Jiang, J., Cusack, M., 2014. Biomineral proteins from Mytilus edulis mantle tissue transcriptome. Mar. Biotechnol. 16, 34-45.

Picone, B., Rhode, C., Roodt-Wilding, R., 2015. Transcriptome profiles of wild and cultured South African abalone, Haliotis midae. Mar. Genomics 20, 3-6.

Berland, S., Marie, A., Duplat, D., Milet, C., Sire, J.Y., Bedouet, L., 2011. Coupling proteomics and transcriptomics for the identification of novel and variant forms of mollusk shell proteins: a study with $P$. margaritifera. Chembiochem 12, 950-961.

Marie, B., Jackson, D.J., Ramos-Silva, P., Zanella-Cleon, I., Guichard, N., Marin, F., 2013. The shell-forming proteome of Lottia gigantea reveals both deep conservations and lineage-specific novelties. FEBS J. 280, 214-232.

Bendena, W.G., Donly, B.C., Tobe, S.S., 1999. Allatostatins: a growing family of neuropeptides with structural and functional diversity. Ann. N. Y. Acad. Sci. 897, 311-329

Woodhead, A.P., Stay, B., Seidel, S.L., Khan, M.A., Tobe, S.S., 1989. Primary structure of four allatostatins: neuropeptide inhibitors of juvenile hormone synthesis. Proc. Natl. Acad. Sci. U. S. A. 86, 5997-6001.

Hergarden, A.C., Tayler, T.D., Anderson, D.J., 2012. Allatostatin-A neurons inhibit feeding behavior in adult Drosophila. Proc. Natl. Acad. Sci. U. S. A. 109, 3967-3972.

Aguilar, R., Maestro, J.L., Vilaplana, L., Pascual, N., Piulachs, M.D., Belles, X., 2003. Allatostatin gene expression in brain and midgut, and activity of synthetic allatostatins on feeding-related processes in the cockroach Blattella germanica. Regul. Pept. 115, 171-177.

Spit, J., Badisco, L., Verlinden, H., Van Wielendaele, P., Zels, S., Dillen, S., Vanden Broeck, J. 2012. Peptidergic control of food intake and digestion in insects. Can. J. Zool. 90, 489-506.

Hauser, F., Cazzamali, G., Williamson, M., Park, Y., Li, B., Tanaka, Y., Predel, R., Neupert, S. Schachtner, J., Verleyen, P., Grimmelikhuijzen, C.J., 2008. A genome-wide inventory of neurohormone GPCRs in the red flour beetle Tribolium castaneum. Front Neuroendocrinol. 29, 142-165.

Lenz, C., Williamson, M., Grimmelikhuijzen, C.J., 2000. Molecular cloning and genomic organization of a second probable allatostatin receptor from Drosophila melanogaster. Biochem. Biophys. Res. Commun. 273, 571-577.

Cardoso, J.C., Felix, R.C., Fonseca, V.G., Power, D.M., 2012. Feeding and the rhodopsin family g-protein coupled receptors in nematodes and arthropods. Front. Endocrinol. 3, 157.

Brown, R.E., Imran, S.A., Ur, E., Wilkinson, M., 2008. KiSS-1 mRNA in adipose tissue is regulated by sex hormones and food intake. Mol. Cell. Endocrinol. 281, 64-72.

Fang, P., He, B., Shi, M., Kong, G., Dong, X., Zhu, Y., Bo, P., Zhang, Z., 2015. The regulative effect of galanin family members on link of energy metabolism and reproduction. Peptides.

Lang, R., Gundlach, A.L., Kofler, B., 2007. The galanin peptide family: receptor pharmacology, pleiotropic biological actions, and implications in health and disease. Pharmacol. Ther. 115, 177-207. 
Amores, A., Catchen, J., Ferrara, A., Fontenot, Q., Postlethwait, J.H., 2011. Genome evolution and meiotic maps by massively parallel DNA sequencing: spotted gar, an outgroup for the teleost genome duplication. Genetics 188, 799-808.

Venkatesh, B., Lee, A.P., Ravi, V., Maurya, A.K., Lian, M.M., Swann, J.B., Ohta, Y., Flajnik, M.F. Sutoh, Y., Kasahara, M., Hoon, S., Gangu, V., Roy, S.W., Irimia, M., Korzh, V., Kondrychyn, I., Lim, Z.W., Tay, B.H., Tohari, S., Kong, K.W., Ho, S., Lorente-Galdos, B. Quilez, J., Marques-Bonet, T., Raney, B.J., Ingham, P.W., Tay, A., Hillier, L.W., Minx, P., Boehm, T., Wilson, R.K., Brenner, S., Warren, W.C., 2014. Elephant shark genome provides unique insights into gnathostome evolution. Nature 505, 174-179.

Pasquier, J., Lafont, A.G., Tostivint, H., Vaudry, H., Rousseau, K., Dufour, S., 2012. Comparative evolutionary histories of kisspeptins and kisspeptin receptors in vertebrates reveal both parallel and divergent features. Front. Endocrinol. 3, 173.

Smith, S.A., Wilson, N.G., Goetz, F.E., Feehery, C., Andrade, S.C., Rouse, G.W., Giribet, G., Dunn, C.W., 2011. Resolving the evolutionary relationships of molluscs with phylogenomic tools. Nature 480, 364-367.

Kocot, K.M., Cannon, J.T., Todt, C., Citarella, M.R., Kohn, A.B., Meyer, A., Santos, S.R., Schander, C., Moroz, L.L., Lieb, B., Halanych, K.M., 2011. Phylogenomics reveals deep molluscan relationships. Nature 477, 452-456.

Gonzalez, V.L., Andrade, S.C., Bieler, R., Collins, T.M., Dunn, C.W., Mikkelsen, P.M., Taylor, J.D., Giribet, G., 2015. A phylogenetic backbone for Bivalvia: an RNA-seq approach. Proc. Biol Sci/R. Soc. 282, 20142332.

Plazzi, F., Ceregato, A., Taviani, M., Passamonti, M., 2011. A molecular phylogeny of bivalve mollusks: ancient radiations and divergences as revealed by mitochondrial genes. PLoS One 6, e27147.

Cunha, R.L., Grande, C., Zardoya, R., 2009. Neogastropod phylogenetic relationships based on entire mitochondrial genomes. BMC Evol. Biol. 9, 210.

Jacobs, D.K., Wray, C.G., Wedeen, C.J., Kostriken, R., DeSalle, R., Staton, J.L., Gates, R.D., Lindberg, D.R., 2000. Molluscan engrailed expression, serial organization, and shell evolution. Evol. Dev. 2, 340-347.

Uliano-Silva, M., Americo, J.A., Brindeiro, R., Dondero, F., Prosdocimi, F., Rebelo Mde, F., 2014. Gene discovery through transcriptome sequencing for the invasive mussel Limnoperna fortunei. PLoS One 9, e102973.

Raghavan, N., Knight, M., 2006. The snail (Biomphalaria glabrata) genome project. Trends Parasitol. 22, 148-151.
Artigaud, S., Thorne, M.A., Richard, J., Lavaud, R., Jean, F., Flye-Sainte-Marie, J., Peck, L.S., Pichereau, V., Clark, M.S., 2014. Deep sequencing of the mantle transcriptome of the great scallop Pecten maximus. Mar. Genomics 15, 3-4.

Bettencourt, R., Pinheiro, M., Egas, C., Gomes, P., Afonso, M., Shank, T., Santos, R.S., 2010. High-throughput sequencing and analysis of the gill tissue transcriptome from the deep-sea hydrothermal vent mussel Bathymodiolus azoricus. BMC Genomics 11, 559.

Ding, J., Zhao, L., Chang, Y., Zhao, W., Du, Z., Hao, Z., 2015. Transcriptome sequencing and characterization of Japanese scallop Patinopecten yessoensis from different shell color lines. PLoS One 10, e0116406.

Saunders, S.E., Burke, J.F., Benjamin, P.R., 2000. Multimeric CREB-binding sites in the promoter regions of a family of G-protein-coupled receptors related to the vertebrate galanin and nociceptin/orphanin-FQ receptor families. Eur. J. Neurosci. 12, 2345-2353.

Kumar, S., Nei, M., Dudley, J., Tamura, K., 2008. MEGA: a biologist-centric software for evolutionary analysis of DNA and protein sequences. Brief. Bioinform. 9, 299-306.

Ronquist, F. Teslenko, M. van der Mark, P. Ayres, D.L., Darling A. Hohna, S., Larget, B. Liu, L., Suchard, M.A., Huelsenbeck, J.P., 2012. MrBayes 3.2: efficient Bayesian phylogenetic inference and model choice across a large model space. Syst. Biol. 61, 539-542.

Abascal, F., Zardoya, R., Posada, D., 2005. ProtTest: selection of best-fit models of protein evolution. Bioinformatics 21, 2104-2105.

Cropper, E.C., Miller, M.W., Tenenbaum, R., Kolks, M.A., Kupfermann, I., Weiss, K.R., 1988. Structure and action of buccalin: a modulatory neuropeptide localized to an identified small cardioactive peptide-containing cholinergic motor neuron of Aplysia californica. Proc. Natl. Acad. Sci. U. S. A. 85, 6177-6181.

Miller, M.W., Beushausen, S., Cropper, E.C., Eisinger, K., Stamm, S., Vilim, F.S., Vitek, A., Zajc, A., Kupfermann, I., Brosius, J., et al., 1993. The buccalin-related neuropeptides: isolation and characterization of an Aplysia cDNA clone encoding a family of peptide cotransmitters. J. Neurosci. 13, 3346-3357.

Razkin, O., Gomez-Moliner, B.J., Prieto, C.E., Martinez-Orti, A., Arrebola, J.R., Munoz, B., Chueca, L.J., Madeira, M.J., 2015. Molecular phylogeny of the western Palaearctic Helicoidea (Gastropoda, Stylommatophora). Mol. Phylogenet. Evol. 83, 99-117. 